\title{
Morpho-genetic Diversity and Anti-bacterial Activity in Root Extracts of Nine Solanaceous Species
}

\author{
D.T. Jeyakumar, U.H.A.J.De Silva ${ }^{1}$, D.R.R.P. Dissanayake ${ }^{1}$ \\ M.D.M.Chamikara ${ }^{1}$ and S.D.S.S. Sooriyapathirana ${ }^{1^{*}}$ \\ Postgraduate Institute of Science, \\ University of Peradeniya, \\ Sri Lanka
}

\begin{abstract}
The family Solanaceae is immensely important because it has many species with food and medicinal values. There are nine major Solanaceous spp. Namely $\underline{S}$. Melongena L. (Wambatu and Elabatu), $\underline{S}$. virginianum L. (Katuwelbatu), $\underline{S} . \underline{\text { torvum }} S \underline{\text { w. }}$.

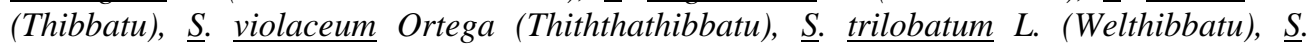

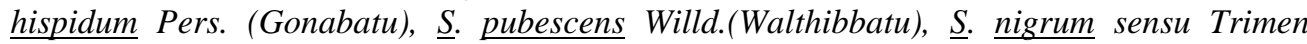
(Small Kalukenweriya) and Datura stramonium L.(Sudu aththana) collected from Uva Province, Sri Lanka, a prominent area of growing these species. Currently these species are underutilized in spite of their medicinal importance. No detailed morpho-genetic and medicinal level characterization of these species has been reported to promote their economic use. Therefore, the present study was conducted to assess the morpho-genetic diversity and the antibacterial activity of these Solanaceous spp. The plant height, canopy width and leaf and fruit morphology were highly variable among these species. DNA barcoding using locus matK revealed a total of eight haplotypes. The polymorphism in matK locus is not diverse enough to set the species limit of the genotypes within $\underline{S}$. melongena and to distinguish Thiththathibbatu from Walthibbatu. The antibacterial activity assay using ethanol extracts of roots demonstrated that all these species have inhibitory activity against Gram positive Staphylococcus aureus (NCTC4838) and Gram negative Escherichia coli (JM109).
\end{abstract}

Keywords: matK, Solanum, medicinal plants, antibacterial activity, morphological diversity

\section{INTRODUCTION}

Solanaceae is an economically important family which consists of many species used for medicinal, culinary, cosmetic and ornamental purposes (Mueller et al., 2005; Sekara et al., 2007). The genus Solanum comprises nearly half of the species classified under family Solanaceae (102 genera and 3000 species). S. melongena (brinjal or eggplant) fruits contain carbohydrates, crude fibre, protein, vitamins and minerals (Edem et al., 2009; Chinedu et al., 2011) which are essential components in human diet. The fruits of eggplants and related species contain very high amount of ascorbic and linoleic acids along with valuable flavonoids, alkaloids, tannins, saponins and numerous phytochemicals (Chen et al., 2009; Chinedu et al., 2011; Ogundajo et al., 2013).

\footnotetext{
${ }^{1}$ Department of Molecular Biology and Biotechnology, Faculty of Science, University of Peradeniya, Sri Lanka *Corresponding Author:sunethss09@gmail.com
} 
Medicinal plants possess greater significance in current medical practices and the medicinally valuable Solananeous species are highly important in this context (Nadkarni, 1927). The World Health Organization (WHO) has declared that the monetary value of medicinal plant trade has reached 500 million USD and will be increased up to more than five trillion USD in the upcoming years (WHO, 2013) since herbal medicines are proven as less toxic with fewer side effects compared to synthetic medicines (Pari and Umamaheswari, 2000). Many domesticated Solanaceous species are used for therapeutic purposes and in steroid industry as they are rich in phytochemicals namely diosgenin and solasodine (Gbile and Adesina, 1988). Avicenna, the father of modern medicine, stated that "eggplant is the medicinal vegetable of modern world" (Sekara et al., 2007). Nasunin, a flavonoid found in eggplants known to protect cell membranes from damages by acting as an antioxidant (Noda et al., 2000) and other flavonoids in eggplants confer hypolipidemic effects (Sudheesh et al., 1997). Because of the presence of valuable flavonoids and alkaloids (Trease and Evans, 2011), Solanum spp. have been routinely utilized in indigenous medicine to cure numerous ailments including obesity, asthma, allergic rhinitis, nasal catarrh, skin infections, swollen joint-pains, gastro-esophageal reflux, constipation, dyspepsia, diabetes, glaucoma, rheumatism, hyperlipidemia, cold, fever and dizziness (Igwe et al., 2003; Odetola et al., 2004; Bello et al., 2005). The saponins in eggplants can reduce high blood pressure and prevent cancer (Dhellat et al., 2006) and also used as adjuvants in vaccines (Ross and Kassum, 2012) along with solasoline, solamargin and diosgenin (Saijo et al., 1982). Several studies revealed that Solanaceous species contain many phytochemicals such as tropein, sapagenin, tomatidine, solverbascine, progesterone, 16-progenolone and yamogenin (Segal et al., 1977; Adam et al., 1979 and 1980; Jain and Sahoo, 1981a and 1981b; Bose and Gosh, 1980). The phenolic compounds present in Solanaceous plants are used in the preparation of sunscreens (Dobson, 2010). Solanaceous species, S. xanthocarpum, S. torvum, S. nigrum, $S$. trilobatum and $S$. melongena possess inhibitory effects against the bacterial pathogens Psuedomonas aeuroginosa, Bacillus subtilis and B. typhi (Raj and Suchithra, 2009; Doss et al., 2009; Sheeba, 2010). Solanum spp. are widely used as a source of fodder, fuel, dye and ink (Fontem and Schippers, 2004; Devi et al., 2012).

In Sri Lanka, Solanum spp. are generally known as 'Batu' (in Sinhala) and 'Kaththiri' (in Tamil). There are 10 species of batu found in Sri Lanka, namely S. melongena (Wambatu, Elabatu), S. virginianum (Katuwelbatu), S. torvum (Thibbatu), S. violaceum (Thiththathibbatu), S. trilobatum (Welthibbatu), S. hispidum (Gonabatu), S. pubescens (Walthibbatu), S. lasiocarpum (Malabatu) and S. capsicoides (Dehelbatu) (Dassanayake and Fosberg, 1988). These Solanum spp. except S. lasiocarpum and S. capsicoides are predominantly grown in $U v a$ Province, Sri Lanka. The important medicinal values of these Solanaceous species are given in Table 1. The rural livelihood of the Uva Province greatly depends on subsistent farming. There is a significant demand for the roots of medicinally important Solanaceous species that are commonly grown in Uva Province. However, they are still in the underutilized status due to socio-economic reasons and lack of morphological and biomolecular studies to efficiently characterize different species. However, India has paid significant attention on these Solanaceous species and characterized them for efficient utilization in the herbal medicine market and Ayurvedic medical practices (Ven Murthy et al., 2010; Tamboli et al., 2015).

If the Solanaceous species found in a certain area are to be exploited economically, they must be morphologically characterized as the first step to document their variation (Yousaf et al., 2008). Then their taxonomic identities can be established using the sequences of DNA barcoding loci such as $m a t K$ ( $\mathrm{Li}$ and Zhou, 2007; Gao et al., 2008), a quickly evolving coding region in plastid genomes (Fazekas, 2008; Lahaye, 2008). 
Although the roots of Solanaceous species are used in Sri Lankan Ayurvedic medical practices and herbal medical preparations, their exact bio-activities have not been characterized. Especially it is imperative to know the antibacterial activity present in the roots to efficiently utilize them in herbal medicine. Therefore, the present study was conducted to assess the morpho-genetic diversity of commonly found Solanaceous species in the Uva Province and to document the antibacterial activity of their roots against model pathogenic bacterial strains.

\section{MATERIALS AND METHODS}

\section{Sample Collection}

A total of eight species in the genus Solanum and as an out-group, Sudu Aththana (Datura stramonium), a Solanaceous species, were collected from the areas Badulla, Bandarawela, Welimada, Haputale and Wellawaya in Uva Province. Two Wambatu and four Elabatu cultivars were collected from S. melongena (Table 1). Henceforth, these eight species and six different cultivars of $S$. melongena are referred to as genotypes. The morphological parameters of shoots, leaves and fruits were recorded using five randomly selected plants/genotype and immature shoots were collected and stored at $-80{ }^{\circ} \mathrm{C}$ for DNA extraction.

Table 1. Solanaceous species/genotypes and their important medicinal properties

\begin{tabular}{|c|c|c|}
\hline \multicolumn{2}{|c|}{ Species } & \multirow{2}{*}{ Medicinal properties/uses } \\
\hline Vernacular name & Botanical name $^{\$}$ & \\
\hline Gonabatu & S. hispidum & 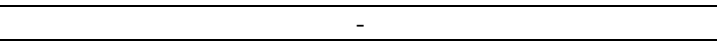 \\
\hline Katuwelbatu & $\begin{array}{l}\text { S. virginianum } \\
\text { S. surattense } \\
\text { S. xanrhocarpum } \\
\text { (Britto } \text { et al., 2011; } \\
\text { Abbas } \text { et al., 2014) }\end{array}$ & $\begin{array}{l}\text { - A component in Ayurvedic Medical Preparations (AMP) } \\
\text { Dashamoolarishtaya and Lagupanchamula (Jayanthy et } \\
\text { al., 2012). } \\
\text { Use to treat itching, fever, cough and cold; make adipose } \\
\text { issues thinner; rectify the problems in seminal } \\
\text { ejaculation (Singh et al., 1996; Devi et al., 2012). } \\
\text { Possess larvicidal property against Anopheles spp., Aedes } \\
\text { spp. and Culex spp. (Bansal et al., 2009). } \\
\text { - Has antidiabetic potential (Gupta } \text { et al., 2005). }\end{array}$ \\
\hline $\begin{array}{l}\text { * Large Elabatu } \\
\text { * Long Elabatu } \\
\text { * Round Elabatu } \\
\text { without prickles } \\
\text { * Round Elabatu } \\
\text { with prickles }\end{array}$ & S. melongena & $\begin{array}{l}\text { - A component in AMPs Dashamoolarishtaya and } \\
\text { Lagupanchamula (Jayanthy et al., 2012). } \\
\text { Possess anticonvulsant (Adesina, 1985), analgesic, } \\
\text { sedative, hypotensive, antipyretic and cardiovascular } \\
\text { healing properties (Vohora et al., 1984; Ojewole and } \\
\text { Adesina, 1983). } \\
\text { Act as anti-inflammatory agents, menopause controllers, } \\
\text { antioxidants, free radical scavengers, anti-allergic and } \\
\text { antimicrobial substances (De Sousa et al., 2007). } \\
\text { Protects cell membrane from damages by acting as an } \\
\text { antioxidant (Noda et al., 2000) and has hypolipidemic } \\
\text { effect (Sudheesh et al., 1997). }\end{array}$ \\
\hline Sudhu Aththana & Datura stramonium & $\begin{array}{l}\text { Possess analgesic, antiasthmatic (Soni et al., 2012), } \\
\text { antioxidant (Kumar et al., 2008) and antibacterial } \\
\text { properties (Taye } \text { et al., 2011). }\end{array}$ \\
\hline $\begin{array}{l}\text { Small } \\
\text { Kalukenweriya }\end{array}$ & $\begin{array}{l}\text { S. } \text { nigrum } \\
\text { S. americanum } \\
\text { (Britto } \text { et al., 2011) }\end{array}$ & $\begin{array}{l}\text { - } \quad \text { Act as analgesic and sedative agent with powerful } \\
\text { nacrotic properties (Taherpour et al., 2013) } \\
\text { Important ingredient to cure tuberculosis (Kaushik et al., } \\
\text { 2009) } \\
\text { Use to treat mouth ulcers and other skin diseases (Jain, } \\
\text { 1968; Edmonds and Chewya, 1997) }\end{array}$ \\
\hline
\end{tabular}




\begin{tabular}{|c|c|c|}
\hline & & 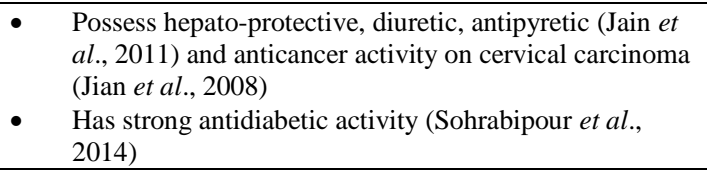 \\
\hline * Thibbatu & S. torvum & $\begin{array}{l}\text { Possess antibacterial effect against } P \text {. aeuroginosa, B. } \\
\text { subtilis and B. typhi (Raj and Suchithra, 2009; Doss et } \\
\text { al., 2009; Sheeba, 2010), Klebsiella pneumoniae } \\
\text { (Parameswariet al., 2012), Salmonella typhi (Ahmed et } \\
\text { al., 2013), E. coli and S. aureus (Singh et al., 2007; } \\
\text { Cuthbertson and Murchie, 2005; Amer } \text { et al., 2013) }\end{array}$ \\
\hline * Thiththathibbatu & $\begin{array}{l}\text { S. violaceum } \\
\text { S. indicum } \\
\text { (Jayanthy et al., } \\
\text { 2012) }\end{array}$ & $\begin{array}{l}\text { - A component in AMPs Dashamoolarishtaya and } \\
\text { Lagupanchamula (Jayanthy et al., 2012) } \\
\text { Use to cure rheumatism, sore throat (Devi et al., 2012), } \\
\text { inflammation, toothache, ascites, oedema and wound } \\
\text { infections (Huang et al., 2008). } \\
\text { Possess antiinflammatory, antihypersensitive and wound } \\
\text { healing properties (Ma et al., 2006; Bahgat et al., 2008). }\end{array}$ \\
\hline Walthibbatu & S. pubescens & 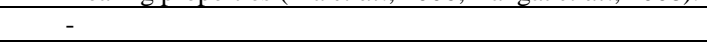 \\
\hline $\begin{array}{l}\text { * Wambatu hybrid } \\
\text { (eggplants) } \\
\text { * Wambatu local } \\
\text { (eggplants) }\end{array}$ & S. melongena & $\begin{array}{l}\text { Possess no medicinal value, potentially allergenic if } \\
\text { included in herbal medical preparations (Rao, 2011, } \\
\text { Marasinghe et al., 2016) }\end{array}$ \\
\hline Welthibbatu & S. trilobatum & $\begin{array}{l}\text { - A component in AMPs Dashamoolarishtaya and } \\
\text { Lagupanchamula (Jayanthy et al., 2012) }\end{array}$ \\
\hline
\end{tabular}

\section{Assessment of Morphological Diversity}

The plant height and canopy width at maturity of the field grown plants were measured. The colour of the stem was recorded before maturity (prior to onset of bloom) and at maturity according to Vejdemo-Johansson et al., (2014). The presence of hairs and prickles on the stem at maturity was also recorded. The petiole length, colour (Vejdemo-Johansson et al., 2014) length, breadth, angle of the leaf with stem, the presence of prickles on the leaves and hairs were recorded in five leaves per plant at mature stage as the parameters related to leaf morphology. Similarly, for floral morphological parameters; length and breadth of petals and sepals, flower diameter, stamen length, numbers of prickles in the pedicel and petal colour were recorded. For fruit parameters; orientation of the fruit from the stem, fruit shape, curvature, apex shape, presence of surface hairs, degree of glossiness, colour (VejdemoJohansson et al., 2014) and colour distribution, length, breadth, weight, stalk length and number of prickles in the stalk were recorded at the same growth stage.

\section{Assessment of Molecular Diversity \\ DNA Extraction, PCR and Sequencing}

Genomic DNA was extracted from young tender leaves using Dneasy ${ }^{\circledR}$ Plant Mini Kit (Qiagen, Solna, Sweden) (Catalog No. 69104) and stored at $-20^{\circ} \mathrm{C}$. The PCR was carried out using matK universal barcoding primer pair for plants (forward primer: 5' CGA TCT ATT CAT TCA ATA TTT C 3' and reverse primer: 5' TCTAGCACACGAAAGTCGAAGT3'). DNA amplification was performed in $15 \mu \mathrm{L}$ reactions containing $1 \times$ GoTaq ${ }^{\circledR}$ Green Master Mix (Promega Corporation, Madison, Wisconsin, USA, Catalog No. M7122), $0.2 \mu \mathrm{M}$ each of forward and reverse primers and $1.0 \mu \mathrm{L}$ of DNA template $(60 \mathrm{ng} / \mu \mathrm{L})$ employing a Thermal Cycler (Takara, Japan, Catalog No. TP350) under the PCR conditions: initial denaturation of $5 \mathrm{~min}$ at $94{ }^{\circ} \mathrm{C} ; 35$ cycles of $30 \mathrm{sec}$ at $94{ }^{\circ} \mathrm{C} ; 1.5 \mathrm{~min}$ at $48{ }^{\circ} \mathrm{C} ; 2.5 \mathrm{~min}$ at 72 ${ }^{\circ} \mathrm{C}$; and a final extension step of $10 \mathrm{~min}$ at $72{ }^{\circ} \mathrm{C}$. The PCR products were visualized in a $2 \%$ 
ethidium bromide stained agarose gel and purified using Promega Wizard® SV Gel and PCR Clean-Up System (Catalog No. A9282) to remove excess dNTPs, primers and primer dimers. Forward DNA sequencing of the purified PCR fragments of each Solanaceous spp. was carried out using Sanger Sequencing based ABI 3500 Series Genetic Analyzer (Applied Biosystems ${ }^{\circledR}$, Catalog No. 4440462).

\title{
Assessment of Antibacterial Activity of Root Extractions
}

The roots were collected from the plants used for morphological measurements and dried under sunlight. Dried root samples were then crushed into fine particles using a food grade grinder and subjected to ethanol extraction using a rotary evaporator. Extracts were dissolved in Dimethylsulfoxide (DMSO) and alcohol was taken out completely. Antibacterial activity of these extracts were tested using agar disc-diffusion method against two model pathogenic species Escherichia coli (JM109) and Staphylococcus aureus (NCTC 4838). A total volume of $20 \mathrm{ml}$ autoclaved Mueller Hinton Agar (MHA) medium was poured into each sterile petri dish and allowed to solidify. Then $100 \mu \mathrm{L}$ of each bacterial cell culture was spread on separate petri dishes evenly. Autoclaved Whatman filter paper discs having diameter of 6 $\mathrm{mm}$ were moistened with $30 \mu \mathrm{l}$ of each root extract and placed on the medium of the MHA plate. A control was also maintained with DMSO alone. Eventually the inoculated plates were incubated at $37^{\circ} \mathrm{C}$ for 24 hours. The diameter of the zone of inhibition (DZBI) around each paper disc was recorded as an indicator of antibacterial activity. Each experiment was performed in triplicate.

\section{Data Analysis}

The qualitative parameters of the stem, leaves, flowers and fruits were descriptively assessed and recorded. The quantitative parameters of the stem, canopy, leaves, flowers and fruits were subjected to normality testing and GLM procedure using the statistical package SAS 9.1 (SAS Institute, Carry, NC, USA). Pearson's Correlation Coefficients (PCC) were calculated using CORR procedure in SAS among the quantitative morphological parameters of leaves, flowers and fruits separately. The quantitative morphological parameters were subjected to Principal Component (PC) Analysis and the first four calculated PCs were used to perform cluster analysis and dendrogram construction using the algorithms of Average Linkage and Pearson's Distance in Minitab 16 (Minitab Inc., USA). The DNA sequences of the matK region were submitted to GenBank (http://www.ncbi.nlm.nih.gov, GenBank Submission ID: 1920215). The matK barcodes were aligned using Clustal Omega Package (http://www.ebi.ac.uk) and a dendrogram was constructed employing Unwieghted Pair-Wise Group Method using Arithmetic Average (UPGMA) of hierarchical cluster analysis in DARwin Software Version 6.0 (Perrier and Jacquemoud-Collet, 2006; Perrier et al., 2003) (http://darwin.cirad.fr/). The DZBI data of the antibacterial activity against E. coli and $S$. aureus were subjected to ANOVA and mean separation procedure in SAS.

\section{RESULTS AND DISCUSSION}

\author{
Morphological Diversity \\ Plant Height and Canopy Width
}

The mean plant height $(\mathrm{PlH})$ at maturity was significantly highest in the genotypes Thibbatu, Thiththathibbatu and Walthibbatu $(285.0 \mathrm{~cm}, 268.9 \mathrm{~cm}$ and $203.9 \mathrm{~cm}$ respectively). The 
genotypes Wambatu local, Long Elabatu and Round Elabatu were having the mean PlH in the range of $94.0-95.0 \mathrm{~cm}$. Wambatu hybrid was significantly shorter than Wambatu local (mean PlH of $78.8 \mathrm{~cm}$ and $94.9 \mathrm{~cm}$ respectively). The genotypes Katuwelbatu and Welthibbatu had the shortest PlH $(37.1 \mathrm{~cm}$ and $29.1 \mathrm{~cm}$ respectively) out of 14 genotypes studied (Table 2) $(\mathrm{P}<0.05)$. The mean canopy width $(\mathrm{CW})$ was also significantly higher in genotypes Thibbatu, Thiththathibbatu and Walthibbatu. The genotype Round Elabatu with prickles possessed the lowest mean CW (Table 2). The PCC between mean PIH and mean CW was $91.2 \%(\mathrm{P}<0.05)$. The stem colours before maturity and at maturity were highly variable among the genotypes. A total of 13 genotypes except Welthibbatu contained hairs on the stem and the genotypes Gonabatu, Thibbatu and Thiththathibbatu contained prickles in addition to the hairs. There were two distinct genotypes of Round Elabatu in which one genotype contained both hairs and prickles whereas the other genotype contained hairs only. The genotype Welthibbatu contained prickles only (Table 2).

Table 2. Mean plant height (PIH), mean canopy width (CW) and stem chracteristics

\begin{tabular}{|c|c|c|c|c|c|}
\hline \multirow[b]{2}{*}{ Genotype } & \multicolumn{2}{|c|}{ Plant (cm) } & \multicolumn{3}{|c|}{ Stem } \\
\hline & $\begin{array}{l}\text { Mean } \\
\text { height }\end{array}$ & $\begin{array}{c}\text { Mean } \\
\text { canopy } \\
\text { width }\end{array}$ & $\begin{array}{c}\text { Colour before } \\
\text { maturity }\end{array}$ & $\begin{array}{l}\text { Colour at } \\
\text { maturity }\end{array}$ & $\begin{array}{c}\text { Presence of } \\
\text { hairs and } \\
\text { prickles }\end{array}$ \\
\hline Gonabatu & $140.5^{\mathrm{b}}$ & $149.1^{\mathrm{b}}$ & $\mathrm{I} 10$ & H15 & $\begin{array}{l}\text { Hairs with } \\
\text { prickles }\end{array}$ \\
\hline Katuwelbatu & $37.1^{\mathrm{e}}$ & $59.7^{\mathrm{d}}$ & G14 & G10 & Hairs only \\
\hline Large Elabatu & $94.7^{\mathrm{c}}$ & $92.5^{\mathrm{c}}$ & $\mathrm{I} 06$ & I39 & Hairs only \\
\hline Long Elabatu & $106.5^{\mathrm{c}}$ & $118.5^{\mathrm{c}}$ & I06 & $\mathrm{I} 40$ & Hairs only \\
\hline $\begin{array}{l}\text { Round Elabatu } \\
\text { without prickles }\end{array}$ & $94.1^{\mathrm{c}}$ & $94.4^{\mathrm{c}}$ & I06 & $\mathrm{I} 40$ & Hairs only \\
\hline $\begin{array}{l}\text { Round Elabatu with } \\
\text { prickles }\end{array}$ & $50.9^{\mathrm{e}}$ & $36.9^{\mathrm{e}}$ & I06 & $\mathrm{I} 40$ & $\begin{array}{l}\text { Hairs with } \\
\text { prickles }\end{array}$ \\
\hline SudhuAththana & $154.0^{\mathrm{b}}$ & $166.2^{\mathrm{b}}$ & G15 & G10 & Hairs only \\
\hline Small Kalukenweriya & $62.1^{\mathrm{d}}$ & $51.0^{\mathrm{d}}$ & G16 & H15 & Hairs only \\
\hline Thibbatu & $285.0^{\mathrm{a}}$ & $238.8^{\mathrm{a}}$ & G14 & E11 & $\begin{array}{l}\text { Hairs with } \\
\text { prickles }\end{array}$ \\
\hline Thiththathibbatu & $268.9^{\mathrm{a}}$ & $329.1^{\mathrm{a}}$ & F13 & G10 & $\begin{array}{l}\text { Hairs with } \\
\text { prickles }\end{array}$ \\
\hline Walthibbatu & $203.9^{\mathrm{a}}$ & $253.9^{\mathrm{a}}$ & E12 & E14 & Hairs only \\
\hline Wambatu hybrid & $78.8^{\mathrm{d}}$ & $85.7^{\mathrm{c}}$ & F14 & G14 & Hairs only \\
\hline Wambatu local & $94.9^{c}$ & $93.1^{\mathrm{c}}$ & H14 & G08 & Hairs only \\
\hline Welthibbatu & $29.1^{\mathrm{e}}$ & $50.7^{\mathrm{d}}$ & F14 & G07 & $\begin{array}{l}\text { Prickles } \\
\text { only }\end{array}$ \\
\hline
\end{tabular}

Colour codes are according to Vejdemo-Johansson et al., (2014).

Means denoted by the same letters within the columns are not significantly different at $\mathrm{P}<0.05$.

Leaf Morphology

The mean petiole length (PL) was the highest in Katuwalbatu and Sudhu Aththana $(5.7 \mathrm{~cm}$ and $5.5 \mathrm{~cm}$ respectively) and the lowest in Small Kalukenweriya $(2.1 \mathrm{~cm})$. The mature leaf colour was visualized as four different classes. The mean leaf length (LL) and the mean leaf breadth (LB) were also significantly different among the genotypes. The mean leaf tip angle (LTA) was also found to be significantly variable among the genotypes. The genotypes 
Gonabatu, Sudhu Aththana, Small Kalukenweriya, Wambatu local and Walthibbatu were having a LTA close to the size of a right angle. The Wambatu hybrid had the LTA of $76.7^{\circ}$ compared to that of Wambatu local $\left(92.0^{\circ}\right)(\mathrm{P}<0.05)$. The genotype Katuwelbatu contained significantly higher number of prickles (65.5) and the genotypes Gonabtu, Round Elabatu with prickles, Thibbatu, Thiththathibbatu contained some prickles and a total of eight genotypes did not possess prickles. Gonabatu and Walthibbatu contained many hairs on the leaves whereas the leaves of genotype Katuwelbatu did not contain hairs. There were six genotypes with intermediate number of hairs on the leaves (Table 3).

All the quantitative parameters of the leaf morphology were significantly correlated to each other except LB and LTA. The LL and LB were significantly, positively and very highly correlated (PCC of $0.83, \mathrm{P}<0.05$ ). The LL, PL and the number of prickles per leaf were significantly and negatively correlated with LTA and the strength of correlation was not very high ( $\mathrm{PCC}$ of $0.18-0.23 \%, \mathrm{P}<0.0001)$ (Table4). The leaf shapes of the genotypes are given in Plate 1.

Table 3. Variation in leaf morphology

\begin{tabular}{|c|c|c|c|c|c|c|c|}
\hline Genotype & $\begin{array}{c}\text { Mean } \\
\text { petiole } \\
\text { length }(\mathrm{cm})\end{array}$ & $\begin{array}{c}\text { Colour } \\
\text { at } \\
\text { maturity }\end{array}$ & $\begin{array}{c}\text { Mean } \\
\text { length } \\
(\mathrm{cm})\end{array}$ & $\begin{array}{c}\text { Mean } \\
\text { breadth } \\
(\mathrm{cm})\end{array}$ & $\begin{array}{l}\text { Mean } \\
\text { tip } \\
\text { angle }^{\circ}\end{array}$ & $\begin{array}{c}\text { Mean } \\
\text { no of } \\
\text { prickles }\end{array}$ & $\begin{array}{c}\text { Abundance } \\
\text { of } \\
\text { hairs* }\end{array}$ \\
\hline Gonabatu & $4.6^{\mathrm{b}}$ & G14 & $27.5^{\mathrm{a}}$ & $22.4^{\mathrm{a}}$ & $82.7^{b}$ & $5.9^{\mathrm{d}}$ & 3 \\
\hline Katuwelbatu & $5.7^{\mathrm{a}}$ & F14 & $12.6^{\mathrm{d}}$ & $13.1^{\mathrm{b}}$ & $61.5^{\mathrm{c}}$ & $65.5^{\mathrm{a}}$ & 0 \\
\hline Large Elabatu & $4.4^{\mathrm{b}}$ & G14 & $15.6^{\mathrm{c}}$ & $10.7^{\mathrm{d}}$ & $74.0^{\mathrm{b}}$ & $0.0^{\mathrm{g}}$ & 2 \\
\hline Long Elabatu & $3.3^{\mathrm{c}}$ & H15 & $10.7^{\mathrm{e}}$ & $8.1^{\mathrm{e}}$ & $67.2^{\mathrm{c}}$ & $0.0^{\mathrm{g}}$ & 2 \\
\hline $\begin{array}{l}\text { Round Elabatu } \\
\text { without prickles }\end{array}$ & $2.7^{\mathrm{d}}$ & G14 & $11.4^{\mathrm{e}}$ & $7.8^{\mathrm{e}}$ & $75.2^{\mathrm{b}}$ & $0.0^{\mathrm{g}}$ & 2 \\
\hline $\begin{array}{l}\text { Round Elabatu } \\
\text { with prickles }\end{array}$ & $2.7^{\mathrm{d}}$ & F15 & $9.3^{\mathrm{f}}$ & $7.0^{\mathrm{e}}$ & $55.0^{\mathrm{c}}$ & $13.0^{\mathrm{b}}$ & 2 \\
\hline Sudhu Aththana & $5.5^{\mathrm{a}}$ & G14 & $17.6^{\mathrm{b}}$ & $12.1^{\mathrm{c}}$ & $88.0^{\mathrm{b}}$ & $0.0^{\mathrm{g}}$ & 1 \\
\hline Small & $2.1^{\mathrm{d}}$ & H18 & $4.5^{\mathrm{g}}$ & $2.8^{\mathrm{f}}$ & $90.0^{\mathrm{a}}$ & $0.0^{\mathrm{g}}$ & 0 \\
\hline Kalukenweriya & & & & & & & \\
\hline Thibbatu & $3.1^{\mathrm{c}}$ & G14 & $11.3^{\mathrm{e}}$ & $8.7^{\mathrm{e}}$ & $73.2^{\mathrm{b}}$ & $1.1^{\mathrm{f}}$ & 2 \\
\hline Thiththathibbatu & $2.8^{\mathrm{d}}$ & H15 & $9.2^{\mathrm{f}}$ & $7.1^{\mathrm{e}}$ & $78.7^{\mathrm{b}}$ & $4.3^{\mathrm{e}}$ & 2 \\
\hline Walthibbatu & $5.2^{\mathrm{a}}$ & H15 & $25.7^{\mathrm{a}}$ & $10.4^{\mathrm{e}}$ & $45.2^{\mathrm{d}}$ & $0.0^{\mathrm{g}}$ & 3 \\
\hline Wambatu hybrid & $3.7^{\mathrm{c}}$ & G15 & $12.2^{\mathrm{d}}$ & $8.4^{\mathrm{e}}$ & $76.7^{\mathrm{b}}$ & $0.0^{\mathrm{g}}$ & 1 \\
\hline Wambatu local & $3.4^{\mathrm{c}}$ & F14 & $12.2^{\mathrm{a}}$ & $8.7^{\mathrm{e}}$ & $92.0^{\mathrm{a}}$ & $0.0^{\mathrm{g}}$ & 1 \\
\hline Welthibbatu & $2.3^{\mathrm{d}}$ & G15 & $4.4^{\mathrm{g}}$ & $3.7^{\mathrm{f}}$ & $86.3^{\mathrm{b}}$ & $8.0^{\mathrm{c}}$ & 1 \\
\hline
\end{tabular}

Colour codes are according toVejdemo-Johansson et al., (2014). Mean values denoted by the same letters within the column are not significantly different $(\mathrm{P}<0.05) . * 0$ (none), 1 (few), 2 (intermediate), 3 (many) 


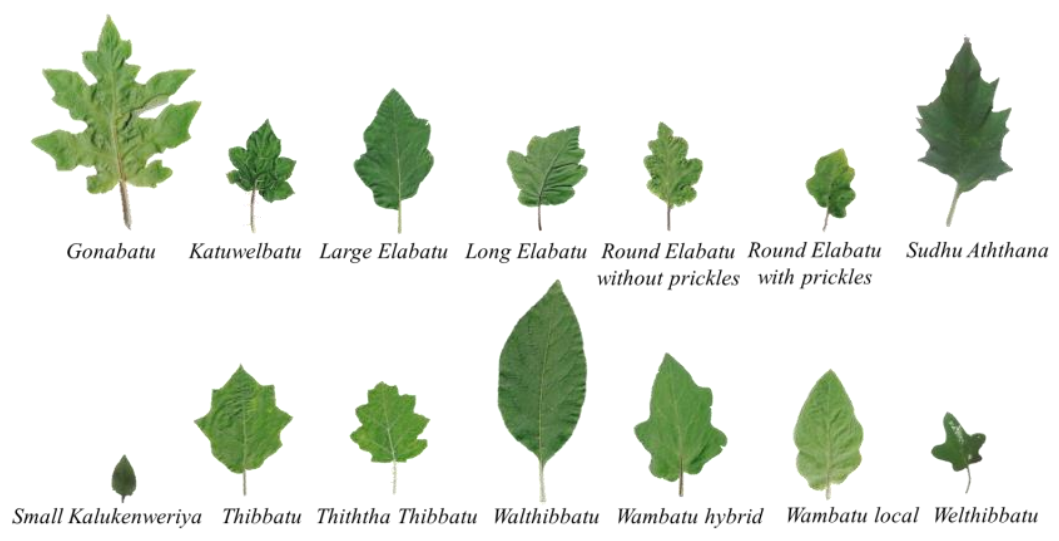

Plate 1. Leaf shapes of the Solanaceous genotypes. (Images are not shown according to the scale, and the size parameters are given in Table 3.)

Table 4. Pearson's Correlation Coefficients (PCC) between quantitative leaf parameters

\begin{tabular}{lcccr}
\hline & Leaf breadth & $\begin{array}{c}\text { Leaf petiole } \\
\text { length }\end{array}$ & No. of prickles/leaf & Tip angle \\
\hline Leaf length & 0.83 & 0.63 & -0.05 & -0.21 \\
Leaf & $* * * *$ & $* * * *$ & $* * * *$ & $* * * *$ \\
breadth & & 0.60 & 0.20 & -0.03 \\
Leaf petiole & & $* * * *$ & $* * * *$ & -0.18 \\
Length & & & 0.32 & $* * * *$ \\
No. of & & & & -0.23 \\
prickles/leaf & & & & $* * * *$ \\
\hline$* * * \mathrm{P}<0.0001$ & & &
\end{tabular}

Flower Morphology

The parameters petal length (PeL), petal breadth (PB), sepal length (SL), sepal breadth (SB), flower diameter (FD), pedicel length (PedL) and stamen length (StL) were significantly variable among the genotypes (Table 5). The genotypes Gonabatu, Katuwelbatu, one cultivar of Round Elabatu, Thibbatu, Wambatulocal and Welthibbatu possessed prickles on the pedicel whereas other eight genotypes did not possess prickles on pedicel. Genotype Sudhu Aththana contained the largest flowers (Table 5). The shape and colour variations of the flowers are given in Plate 2 and petal colour is categorically indicated in Table 5. Except the number of prickles in the flower pedicel, all other quantitative parameters of the flowers indicated significantly positive correlations $(0.63$ - 0.99) (Table 6, $\mathrm{P}<0.0001)$. 
Table 5. Variation in floral morphology

\begin{tabular}{|c|c|c|c|c|c|c|c|c|c|}
\hline \multirow[b]{2}{*}{ Genotype } & \multicolumn{2}{|c|}{ Petal } & \multicolumn{2}{|c|}{ Sepal } & \multicolumn{5}{|c|}{ Flower } \\
\hline & 䒿 & 营 & Е્ّ & 吾 & 离 & 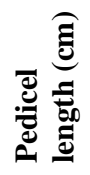 & 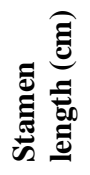 & $\begin{array}{c}\text { No. of } \\
\text { prickles } \\
\text { in the } \\
\text { pedicel }\end{array}$ & $\begin{array}{c}\text { Petal } \\
\text { colour }\end{array}$ \\
\hline Gonabatu & $1.6^{\mathrm{b}}$ & $0.7^{\mathrm{c}}$ & $0.6^{\mathrm{c}}$ & $0.3^{\mathrm{b}}$ & $2.7^{\mathrm{c}}$ & $0.7^{\mathrm{d}}$ & $0.9^{c}$ & $0.5^{\mathrm{d}}$ & B31 \\
\hline Katuwelbatu & $1.3^{\mathrm{b}}$ & $0.6^{\mathrm{c}}$ & $0.3^{\mathrm{d}}$ & $0.2^{\mathrm{b}}$ & $2.3^{\mathrm{b}}$ & $1.7^{\mathrm{c}}$ & $0.9^{\mathrm{c}}$ & $17.2^{\mathrm{a}}$ & B15 \\
\hline Large Elabatu & $2.0^{\mathrm{b}}$ & $1.4^{\mathrm{b}}$ & $0.8^{\mathrm{c}}$ & $0.3^{\mathrm{b}}$ & $3.3^{\mathrm{b}}$ & $1.6^{\mathrm{c}}$ & $0.8^{\mathrm{c}}$ & $0.0^{\mathrm{e}}$ & F35 \\
\hline Long Elabatu & $1.9^{\mathrm{b}}$ & $1.2^{\mathrm{b}}$ & $0.8^{\mathrm{c}}$ & $0.2^{\mathrm{b}}$ & $3.2^{\mathrm{b}}$ & $1.8^{\mathrm{c}}$ & $0.7^{\mathrm{c}}$ & $0.0^{\mathrm{e}}$ & F34 \\
\hline $\begin{array}{l}\text { Round Elabatu } \\
\text { without prickles }\end{array}$ & $1.8^{\mathrm{b}}$ & $1.2^{\mathrm{b}}$ & $0.7^{\mathrm{c}}$ & $0.3^{\mathrm{b}}$ & $2.5^{\mathrm{c}}$ & $1.7^{\mathrm{c}}$ & $1.1^{\mathrm{b}}$ & $0.0^{\mathrm{e}}$ & E35 \\
\hline $\begin{array}{l}\text { Round Elabatu } \\
\text { with prickles }\end{array}$ & $1.1^{\mathrm{b}}$ & $0.6^{\mathrm{c}}$ & $0.4^{\mathrm{d}}$ & $0.2^{\mathrm{b}}$ & $2.0^{\mathrm{c}}$ & $1.1^{\mathrm{c}}$ & $0.5^{\mathrm{c}}$ & $2.5^{\mathrm{c}}$ & E35 \\
\hline SudhuAththana & $9.3^{\mathrm{a}}$ & $5.2^{\mathrm{a}}$ & $4.1^{\mathrm{a}}$ & $3.0^{\mathrm{a}}$ & $6.3^{\mathrm{a}}$ & $3.9^{\mathrm{a}}$ & $7.6^{\mathrm{a}}$ & $0.0^{\mathrm{e}}$ & B32 \\
\hline $\begin{array}{l}\text { Small } \\
\text { Kalukenweriya }\end{array}$ & $1.0^{\mathrm{b}}$ & $0.3^{\mathrm{d}}$ & $0.3^{\mathrm{d}}$ & $0.2^{\mathrm{b}}$ & $1.2^{\mathrm{d}}$ & $1.2^{\mathrm{c}}$ & $0.7^{\mathrm{c}}$ & $0.0^{\mathrm{e}}$ & $\mathrm{C} 12$ \\
\hline Thibbatu & $1.3^{\mathrm{b}}$ & $0.5^{\mathrm{c}}$ & $0.4^{\mathrm{d}}$ & $0.2^{\mathrm{b}}$ & $2.3^{\mathrm{c}}$ & $0.9^{\mathrm{d}}$ & $0.8^{\mathrm{c}}$ & $0.0^{\mathrm{e}}$ & B8 \\
\hline Thiththathibbatu & $1.3^{\mathrm{b}}$ & $0.6^{\mathrm{c}}$ & $0.4^{\mathrm{d}}$ & $0.2^{\mathrm{b}}$ & $2.1^{\mathrm{c}}$ & $1.2^{\mathrm{c}}$ & $0.9^{c}$ & $0.5^{\mathrm{d}}$ & G34 \\
\hline Walthibbatu & $1.0^{\mathrm{b}}$ & $0.4^{\mathrm{d}}$ & $0.4^{\mathrm{d}}$ & $0.2^{\mathrm{b}}$ & $1.5^{\mathrm{d}}$ & $0.3^{\mathrm{d}}$ & $0.4^{\mathrm{c}}$ & $0.0^{\mathrm{e}}$ & F34 \\
\hline Wambatu hybrid & $1.8^{\mathrm{b}}$ & $0.9^{\mathrm{b}}$ & $1.1^{\mathrm{b}}$ & $0.4^{\mathrm{b}}$ & $3.3^{\mathrm{b}}$ & $1.7^{\mathrm{c}}$ & $1.2^{\mathrm{b}}$ & $0.0^{\mathrm{e}}$ & G36 \\
\hline Wambatu local & $2.1^{\mathrm{b}}$ & $1.1^{\mathrm{b}}$ & $1.2^{\mathrm{b}}$ & $0.4^{\mathrm{b}}$ & $3.4^{\mathrm{b}}$ & $2.4^{\mathrm{b}}$ & $1.2^{\mathrm{b}}$ & $4.6^{\mathrm{b}}$ & C35 \\
\hline Welthibbatu & $1.1^{\mathrm{b}}$ & $0.6^{\mathrm{c}}$ & $0.5^{\mathrm{d}}$ & $0.3^{\mathrm{b}}$ & $1.8^{\mathrm{d}}$ & $0.4^{\mathrm{d}}$ & $0.6^{\mathrm{c}}$ & $0.9^{\mathrm{d}}$ & $\mathrm{C} 36$ \\
\hline
\end{tabular}

Colour codes are according to Vejdemo-Johansson et al., (2014).

Mean values denoted by same letters within a column are not significantly different at $\mathrm{P}<0.05$.
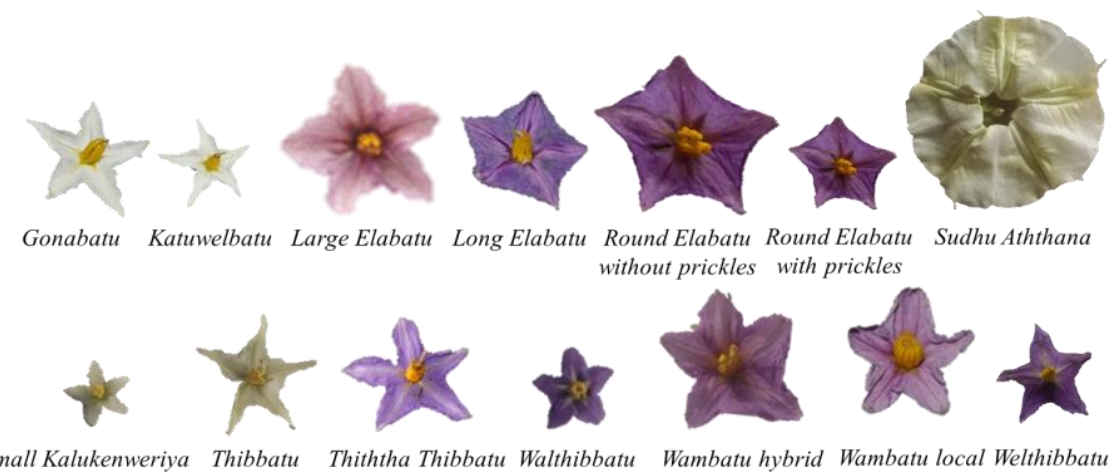

Plate 2. Variation in flower shape of Solanaceous genotypes. 
Table 6. Pearson's Correlation Coefficients among quantitative floral parameters

\begin{tabular}{|c|c|c|c|c|c|c|c|}
\hline & $\begin{array}{c}\text { Petal } \\
\text { breadth }\end{array}$ & $\begin{array}{c}\text { Flower } \\
\text { diameter }\end{array}$ & $\begin{array}{r}\text { Sepal } \\
\text { length }\end{array}$ & $\begin{array}{c}\text { Sepal } \\
\text { breadth }\end{array}$ & $\begin{array}{l}\text { Pedicel } \\
\text { length }\end{array}$ & $\begin{array}{l}\text { Stamen } \\
\text { length }\end{array}$ & $\begin{array}{c}\text { No.of } \\
\text { prickles/pedicel }\end{array}$ \\
\hline $\begin{array}{l}\text { Petal } \\
\text { length }\end{array}$ & $\begin{array}{c}0.98 \\
* * * *\end{array}$ & $\begin{array}{l}0.83 \\
* * * *\end{array}$ & $\begin{array}{l}0.97 \\
* * * *\end{array}$ & $\begin{array}{c}0.98 \\
* * * *\end{array}$ & $\begin{array}{l}0.71 \\
* * * *\end{array}$ & $\begin{array}{c}0.98 \\
* * * *\end{array}$ & 0.00 \\
\hline $\begin{array}{l}\text { Petal } \\
\text { breadth }\end{array}$ & & $\begin{array}{l}0.86 \\
* * * *\end{array}$ & $\begin{array}{l}0.96 \\
* * * *\end{array}$ & $\begin{array}{l}0.94 \\
* * * *\end{array}$ & $\begin{array}{l}0.73 \\
* * * *\end{array}$ & $\begin{array}{l}0.94 \\
* * * *\end{array}$ & 0.00 \\
\hline $\begin{array}{l}\text { Flower } \\
\text { diameter }\end{array}$ & & & $\begin{array}{l}0.87 \\
* * * *\end{array}$ & $\begin{array}{l}0.74 \\
* * * *\end{array}$ & $\begin{array}{l}0.79 \\
* * * *\end{array}$ & $\begin{array}{l}0.76 \\
* * * *\end{array}$ & 0.00 \\
\hline $\begin{array}{l}\text { Sepal } \\
\text { length }\end{array}$ & & & & $\begin{array}{l}0.99 \\
* * * *\end{array}$ & $\begin{array}{l}0.68 \\
* * * *\end{array}$ & $\begin{array}{l}0.95 \\
* * * *\end{array}$ & 0.00 \\
\hline $\begin{array}{l}\text { Sepal } \\
\text { breadth }\end{array}$ & & & & & $\begin{array}{l}0.63 \\
* * * *\end{array}$ & $\begin{array}{l}0.95 \\
* * * *\end{array}$ & 0.07 \\
\hline $\begin{array}{l}\text { Pedicel } \\
\text { length }\end{array}$ & & & & & & $\begin{array}{l}0.73 \\
* * * *\end{array}$ & 0.25 \\
\hline $\begin{array}{l}\text { Stamen } \\
\text { length }\end{array}$ & & & & & & & 0.05 \\
\hline
\end{tabular}

\section{Fruit Morphology}

There were two types of fruit orientation from the stem namely erect and pendent. The fruit shape, curvature and shape of the apex were not highly variable among the genotypes. Walthibbatu was the only genotype containing hairs on the fruit surface. Sudhu Aththana and Walthibbatu had dull appearance of the fruit whereas fruit surface of other genotypes were shiny i.e. with high degree of glossiness. The fruit colour was variable among the genotypes and six genotypes had even colour and eight genotypes had bicolour (Table 7).

Fruit length (FL), fruit breadth (FB) and fruit stalk length (FSL) were significantly variable among the genotypes $(\mathrm{P}<0.05)$. The genotypes Katuwelbatu, one cultivar of Round Elabatu, Wambatu local and Welthibbatu contained prickles on the fruit stalk and genotype Katuwelbatu had the significantly highest number of prickles on the fruit stalk $(15.9, \mathrm{P}<0.05)$ (Table 8). The fruit shapes are given in Plate 3. All measured quantitative fruit parameters had significant and positive correlations with each other. The correlation between FL and FB was 0.44 whereas FL and fruit weight $(\mathrm{FW})$ showed PCC of $0.93(\mathrm{P}<0.0001)$. The FSL was also very highly correlated to the size parameters $(0.50$ to 0.84 of $\mathrm{PCC}, \mathrm{P}<0.0001)$. The number of prickles on the stalk had low correlation coefficient with other fruit parameters despite significance $(0.04$ to 0.20 of PCC, $\mathrm{P}<0.0001)$ (Table 9$)$.

The Principal Components calculated based on the quantitative morphological parameters were subjected to cluster analysis and respective dendrogram is shown in Fig.1. All the Elabatu genotypes were clustered together at $76.8 \%$ of morphological similarly coefficient. Thiththathibbatu and Thibbatu were clustered together at $89.5 \%$ morphological similarly coefficient. However, genotype Katuwelbatu was only $41.3 \%$ similar to the rest of the genotypes. The out group genotype Sudhu Aththana was only exhibiting $12.0 \%$ similarly to the rest of the genotypes (Fig. 1). 
Table 7. The qualitative parameters of fruit morphology in Solanaceous spp.

\begin{tabular}{|c|c|c|c|c|c|c|c|c|c|}
\hline Genotype & & $\begin{array}{l}\text { ॠँ } \\
\text { Еँ }\end{array}$ & 莣 & 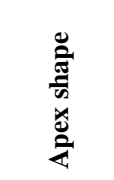 & 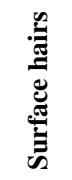 & 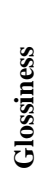 & & & 音 \\
\hline Gonabatu & Erect & Round & None & Round & None & 2 & \multicolumn{2}{|c|}{ G15 } & Even \\
\hline Katuwelbatu & Pendant & Round & None & Round & None & 2 & \multicolumn{2}{|c|}{ D6 } & Even \\
\hline Large Elabatu & Pendant & Round & None & Round & None & 2 & E14 & B14 & Bicolour \\
\hline Long Elabatu & Pendant & Oblong & $\begin{array}{l}\text { Slightly } \\
\text { curved }\end{array}$ & Protruded & None & 2 & D14 & B14 & Bicolour \\
\hline $\begin{array}{l}\text { Round Elabatu } \\
\text { without prickles }\end{array}$ & Pendant & Round & None & Round & None & 2 & E14 & B14 & Bicolour \\
\hline $\begin{array}{l}\text { Round Elabatu with } \\
\text { prickles }\end{array}$ & Pendant & Round & None & Round & None & 2 & F14 & B09 & Bicolour \\
\hline SudhuAththana & Pendant & Round & None & Round & None & 1 & \multicolumn{2}{|c|}{ E14 } & Even \\
\hline $\begin{array}{l}\text { Small } \\
\text { Kalukenweriya }\end{array}$ & Pendant & Round & None & Round & None & 3 & \multicolumn{2}{|c|}{ I32 } & Even \\
\hline Thibbatu & Erect & Round & None & Round & None & 2 & \multicolumn{2}{|c|}{ F16 } & Even \\
\hline Thiththathibbatu & Erect & Round & None & Round & None & 3 & \multirow{2}{*}{\multicolumn{2}{|c|}{$\begin{array}{l}\text { F13 } \\
\text { F14 }\end{array}$}} & Bicolour \\
\hline Walthibbatu & Erect & Round & None & Round & Many & 1 & & & Even \\
\hline Wambatu hybrid & Pendant & $\begin{array}{l}\text { Semi- } \\
\text { long }\end{array}$ & $\begin{array}{l}\text { Slightly } \\
\text { curved }\end{array}$ & Protruded & None & 3 & F36 & A & Bicolour \\
\hline Wambatu local & Pendant & $\begin{array}{l}\text { Semi- } \\
\text { long }\end{array}$ & $\begin{array}{l}\text { Slightly } \\
\text { curved }\end{array}$ & Protruded & None & 3 & $\mathrm{I} 40$ & A & Bicolour \\
\hline Welthibbatu & Pendant & Round & None & Round & None & 3 & \multicolumn{2}{|c|}{ G16 } & Bicolour \\
\hline
\end{tabular}

Colour codes are according to Vejdemo-Johansson et al., (2014).

Glossiness: 1 (dull), 2 (fairly shiny), 3 (shiny)

Table 8. The quantitative morphological parameters of Solanaceous fruitspp.

\begin{tabular}{|c|c|c|c|c|c|}
\hline Genotype & $\begin{array}{l}\text { Length } \\
\text { (cm) }\end{array}$ & $\begin{array}{l}\text { Breadth } \\
\quad(\mathrm{cm})\end{array}$ & $\begin{array}{c}\text { Weight } \\
\text { (g) }\end{array}$ & $\begin{array}{c}\text { Stalk } \\
\text { length }(\mathbf{c m})\end{array}$ & $\begin{array}{c}\text { Mean no. of } \\
\text { prickles in } \\
\text { stalk }\end{array}$ \\
\hline Gonabatu & $1.2^{\mathrm{e}}$ & $1.2^{\mathrm{d}}$ & $1.3^{\mathrm{f}}$ & $1.8^{\mathrm{c}}$ & $0.0^{\mathrm{d}}$ \\
\hline Katuwelbatu & $2.0^{\mathrm{e}}$ & $2.1^{\mathrm{c}}$ & $4.6^{\mathrm{e}}$ & $1.9^{\mathrm{c}}$ & $15.9^{\mathrm{a}}$ \\
\hline Large Elabatu & $3.6^{\mathrm{c}}$ & $4.4^{\mathrm{a}}$ & $34.6^{\mathrm{c}}$ & $4.3^{\mathrm{b}}$ & $0.0^{\mathrm{d}}$ \\
\hline Long Elabatu & $4.4^{\mathrm{b}}$ & $2.6^{\mathrm{c}}$ & $15.0^{\mathrm{d}}$ & $4.5^{\mathrm{b}}$ & $0.0^{\mathrm{d}}$ \\
\hline $\begin{array}{l}\text { Round Elabatu } \\
\text { without prickles }\end{array}$ & $2.4^{\mathrm{d}}$ & $2.5^{\mathrm{c}}$ & $9.0^{\mathrm{e}}$ & $3.8^{\mathrm{b}}$ & $0.0^{\mathrm{d}}$ \\
\hline $\begin{array}{l}\text { Round Elabatu } \\
\text { with prickles }\end{array}$ & $2.3^{\mathrm{d}}$ & $2.3^{\mathrm{c}}$ & $6.2^{\mathrm{e}}$ & $2.4^{\mathrm{c}}$ & $2.1^{\mathrm{b}}$ \\
\hline Sudhu Aththana & $4.8^{\mathrm{b}}$ & $4.5^{\mathrm{a}}$ & $19.3^{\mathrm{d}}$ & $1.9^{\mathrm{c}}$ & $0.0^{\mathrm{d}}$ \\
\hline $\begin{array}{l}\text { Small } \\
\text { Kalukenweriya }\end{array}$ & $0.9^{f}$ & $0.9^{\mathrm{e}}$ & $0.1^{\mathrm{f}}$ & $0.8^{\mathrm{d}}$ & $0.0^{\mathrm{d}}$ \\
\hline Thibbatu & $1.1^{\mathrm{e}}$ & $1.2^{\mathrm{d}}$ & $1.4^{\mathrm{f}}$ & $1.6^{\mathrm{c}}$ & $0.0^{\mathrm{d}}$ \\
\hline Thiththathibbatu & $0.8^{\mathrm{f}}$ & $0.8^{\mathrm{e}}$ & $0.3^{\mathrm{f}}$ & $1.7^{\mathrm{c}}$ & $0.0^{\mathrm{d}}$ \\
\hline Walthibbatu & $1.0^{\mathrm{e}}$ & $0.9^{\mathrm{e}}$ & $0.7^{\mathrm{f}}$ & $0.6^{\mathrm{d}}$ & $0.0^{\mathrm{d}}$ \\
\hline Wambatu hybrid & $16.3^{\mathrm{a}}$ & $3.4^{\mathrm{b}}$ & $64.1^{\mathrm{b}}$ & $6.6^{\mathrm{a}}$ & $0.0^{\mathrm{d}}$ \\
\hline Wambatu local & $16.2^{\mathrm{a}}$ & $4.4^{\mathrm{a}}$ & $85.3^{\mathrm{a}}$ & $7.5^{\mathrm{a}}$ & $0.1^{\mathrm{c}}$ \\
\hline Welthibbatu & $0.9^{\mathrm{f}}$ & $1.0^{\mathrm{d}}$ & $0.6^{\mathrm{f}}$ & $2.1^{\mathrm{c}}$ & $0.3^{\mathrm{c}}$ \\
\hline
\end{tabular}

Mean values denoted by the same letters within the column are not significantly different at $\mathrm{P}<0.05$. 


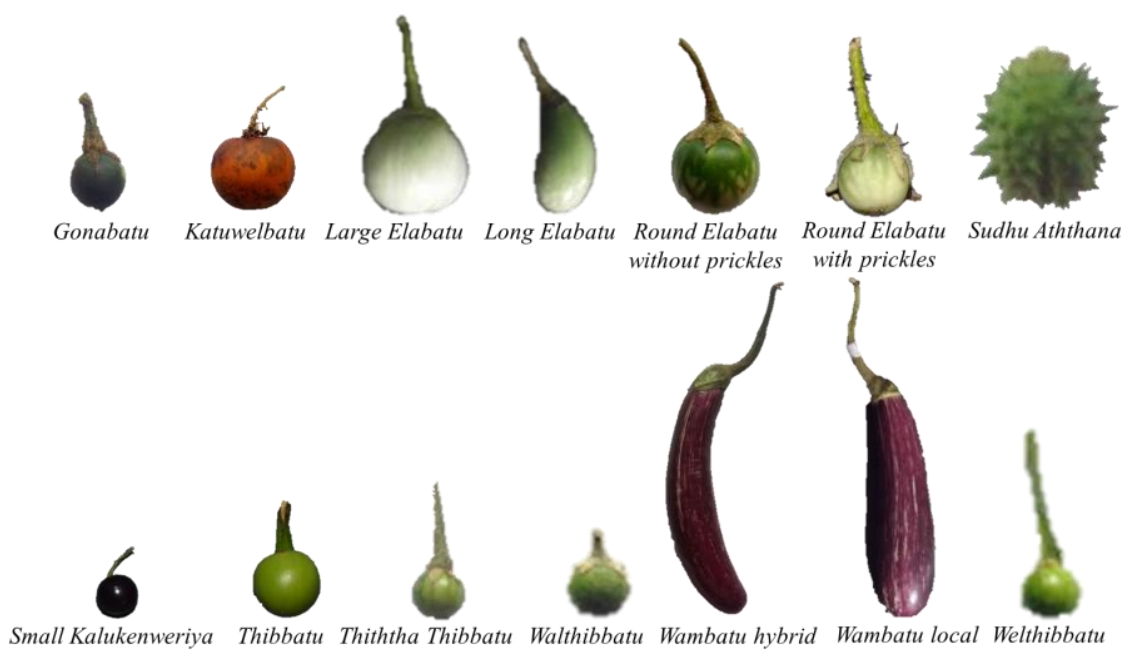

Plate 3. Variation in fruit shape of Solanaceous genotypes.

Table 9. Pearson's Correlation Coefficients (PCC) among quantitative fruit parameters

\begin{tabular}{lcccc}
\hline & $\begin{array}{c}\text { Fruit } \\
\text { breadth }\end{array}$ & Fruit weight & Stalk length & No. of prickles in stalk \\
\hline Fruit length & $0.44 * * * *$ & $0.93 * * * *$ & $0.80 * * * *$ & $0.13 * * * *$ \\
Fruit breadth & & $0.58 * * * *$ & $0.50 * * * *$ & $0.04 * * * *$ \\
Fruit weight & & & $0.84 * * * *$ & $0.14 * * * *$ \\
Stalk length & & & & $0.20 * * * *$ \\
\hline
\end{tabular}

**P $<0.0001$

\section{Genetic Diversity Analysis \\ DNA Barcoding}

PCR based on the matK DNA barcoding primers yielded an amplicon with the length of 936 bp (Fig.2A). The DNA sequence polymorphism within the tested 14 Solanaceous genotypes indicated that there were total of eight haplotypes present and all Wambatu and Elabatu genotypes shared the same haplotype. The genotypes Thiththathibbatu and Walthibbatu also shared a common haplotype. It was clear that other six genotypes were having unique matK haplotypes. A total of 52 Single Nucleotide Polymorphisms (SNPs) were detected within the $m a t K$ locus among the eight haplotypes. All Wambatu and Elabatu cultivars (i.e. S. melongena) got a unique SNP at $388^{\text {th }}$ bp position which was not present in other species. A total of 42 unique SNPs found in Solanaceous spp. Out of the 52 SNPs, 49 were bi-allelic and three were tri-allelic indicating the quickly evolving species specific nature of $m a t K$ region within Solanaceous spp. The $m a t K$ sequences of the 14 species were submitted to GenBank (www.ncbi.nlm.nih.gov) and the GenBank accession numbers are KX258741, KX258742, KX258743, KX258744, KX258745, KX258746, KX258747, KX258748, KX258749, KX258750, KX258751, KX258752, KX258753 and KX258754 according to the order of genotypes given in Table 1.The haplotype variations of the matK region isshown with the colours in Figure 2B. The rooted tree diagram with the evolutionary distances 
Jeyakumar et al.

among the haplotypes is shown in Figure 3. The rooted tree diagram indicated that four Thibbatu cultivars are closely related to $S$. melongena.

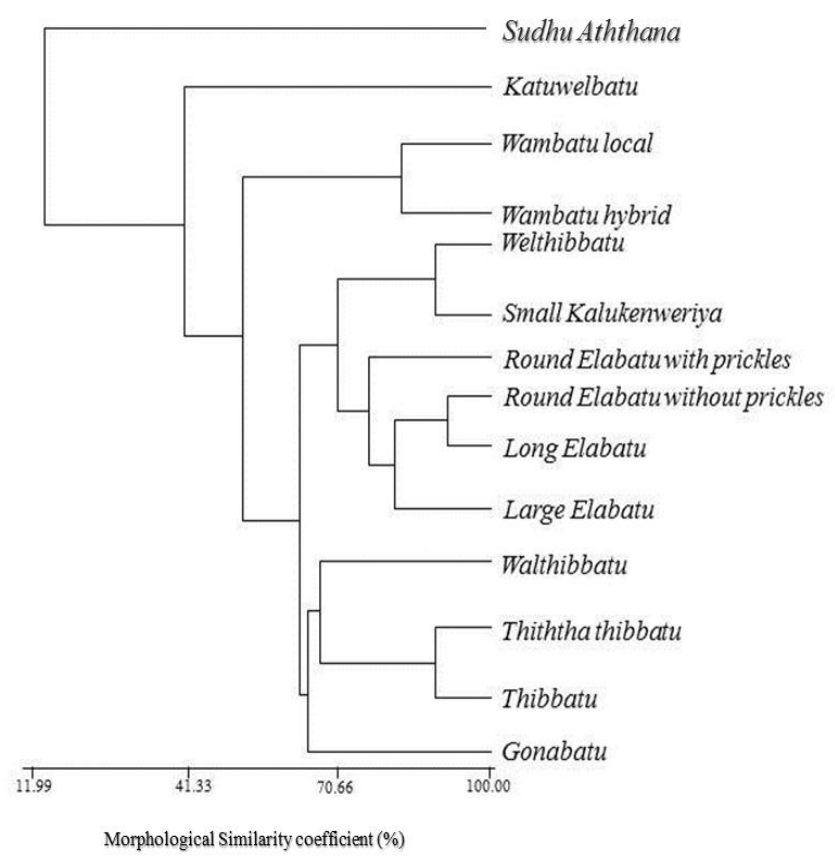

Figure 1. The dendrogram constructed based on the principal components computed using quantitative morphological parameters of flowers, fruits and plants of Solanaceous genotypes. 


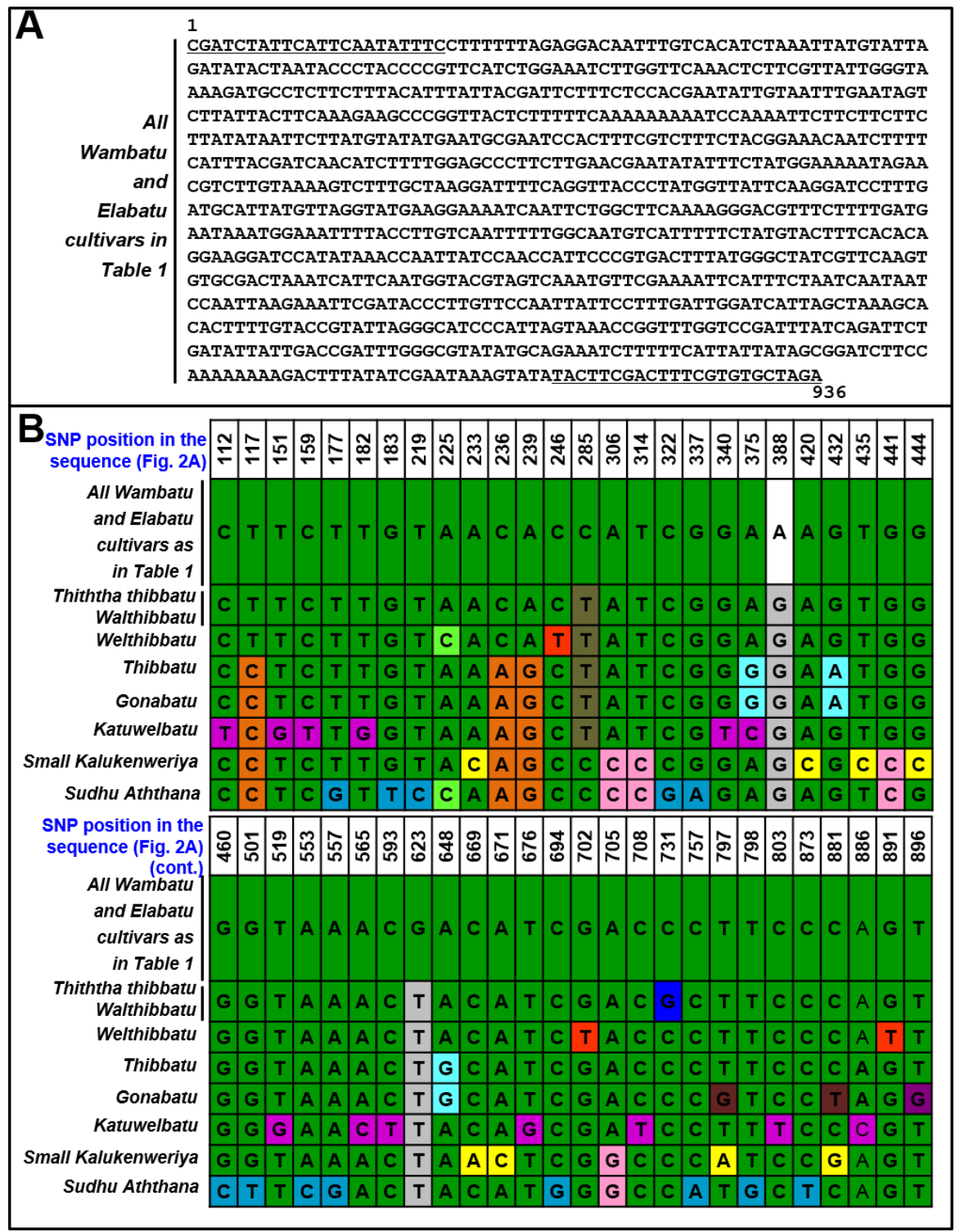

Figure 2. DNA polymorphism in the matKlocus in Solanaceous species.

A: matKDNA sequence of all Wambatu and Elabatu cultivarslisted in Table 1. The forward and reverse matK primers are underlined. The total length of the amplicon is $936 \mathrm{bp}$. The starting and ending bases are shown with the numbers 1 and 936 respectively. B: The SNP positions and the SNP alleles in the matKgenomic locus of Solanaceous species. The SNP positions within Fig.2B are shown in vertically aligned numbers and the names of the genotypes/groups are shown in the left. The SNP alleles are shown in front of each genotypes/group and colour shades for cells are provided to show shared and unique alleles. 


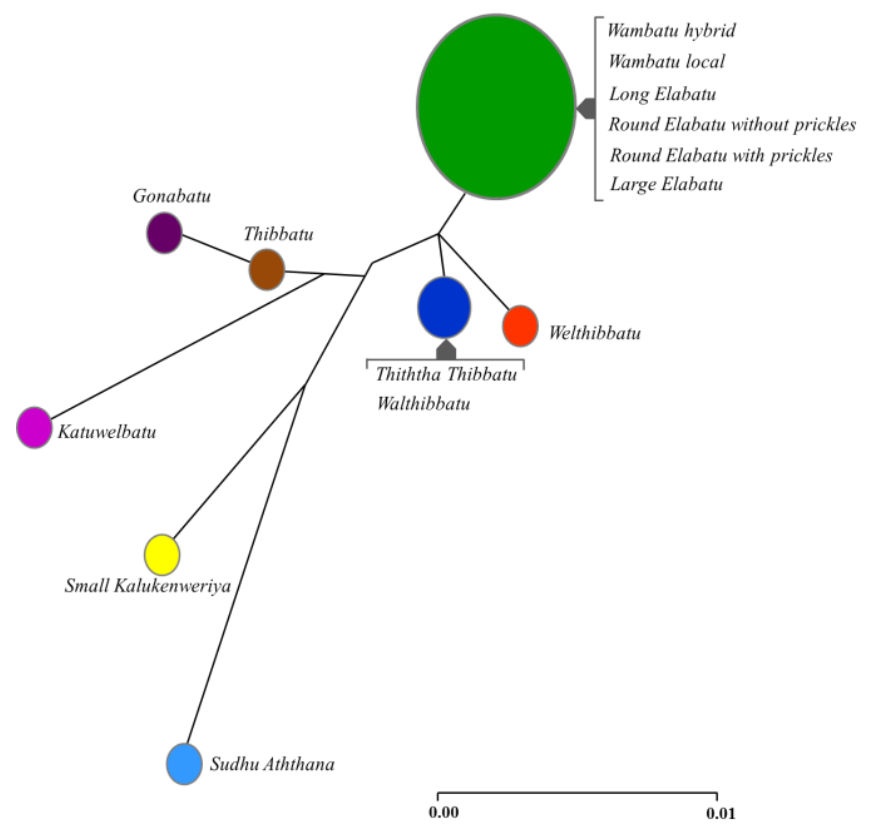

Figure 3. The rooted tree diagram showing genetic diversity of the Solanaceous genotypes based on the DNA sequence polymorphism in matKregion. Scale bar represent 0.01 of genetic divergence.

Antibacterial Activity of Solanaceous spp.

The antibacterial analysis of the root extracts of Solanaceous genotypes exhibited significantly higher activity against Gram negative E. coli and Gram positive S. aureus. The solvent DMSO (i.e. negative control) did not exhibit any antibacterial activity (mean DZBI was $0.0 \mathrm{~mm}$ ) against two bacteria (Table 10). The genotype Gonabatu and Thiththathibbatu exhibited the significantly highest antibacterial activity (mean DZBIs of $10.4 \mathrm{~mm}$ and 10.2 $\mathrm{mm}$ respectively) against E. coli. Other Solanum genotypes also exhibited $7.5 \mathrm{~mm}$ to $9.6 \mathrm{~mm}$ of mean DZBI against E. coli. In general the antibacterial activity was highest against $S$. aureus in comparison to $E$. coli. The highest antibacterial activity on $S$. aureus was shown by the genotype Welthibbatu (13.0 mm of mean DZBI) followed by Gonabatu (11.5 mm mean DZBI). All the other 12 genotypes showed significantly similar antibacterial activity on S.aureus (10.6 mm of mean DZBI for 12 genotypes). 
Table 10. Antibacterial activity of the ethanol extracts prepared from the roots of Solanaceous spp.

\begin{tabular}{|c|c|c|}
\hline \multirow[t]{2}{*}{ Genotype } & \multicolumn{2}{|c|}{$\begin{array}{l}\text { Mean diameter of the zone of inhibition (DZBI } \\
(\mathrm{mm})\end{array}$} \\
\hline & E. coli & S. aureus \\
\hline Gonabatu & $10.4^{\mathrm{a}}$ & $11.5^{\mathrm{b}}$ \\
\hline Katuwelbatu & $8.2^{\mathrm{c}}$ & $10.6^{\mathrm{c}}$ \\
\hline Large Elabatu & $9.4^{\mathrm{b}}$ & $10.8^{\mathrm{c}}$ \\
\hline Long Elabatu & $9.6^{\mathrm{b}}$ & $11.0^{\mathrm{c}}$ \\
\hline $\begin{array}{l}\text { Round Elabatu without } \\
\text { prickles }\end{array}$ & $8.0^{\mathrm{c}}$ & $10.8^{\mathrm{c}}$ \\
\hline Round Elabatu with prickles & $7.7^{\mathrm{d}}$ & $11.0^{\mathrm{c}}$ \\
\hline Sudhu Aththana & $7.5^{\mathrm{d}}$ & $10.4^{\mathrm{c}}$ \\
\hline Small Kalukenweriya & $7.9^{\mathrm{d}}$ & $10.7^{\mathrm{c}}$ \\
\hline Thibbatu & $8.7^{\mathrm{c}}$ & $10.6^{\mathrm{c}}$ \\
\hline Thiththathibbatu & $10.2^{\mathrm{a}}$ & $10.1^{\mathrm{c}}$ \\
\hline Walthibbatu & $7.8^{\mathrm{d}}$ & $10.6^{\mathrm{c}}$ \\
\hline Wambatu hybrid & $7.5^{\mathrm{d}}$ & $10.2^{\mathrm{c}}$ \\
\hline Wambatu local & $7.9^{\mathrm{d}}$ & $10.3^{\mathrm{c}}$ \\
\hline Welthibbatu & $9.0^{\mathrm{b}}$ & $13.0^{\mathrm{a}}$ \\
\hline $\begin{array}{l}\text { Control [Dimethylsulfoxide } \\
\text { (DMSO) only] }\end{array}$ & $0.0^{\mathrm{e}}$ & $0.0^{\mathrm{d}}$ \\
\hline
\end{tabular}

Means denoted by the same letters within each column are not significantly different at $\mathrm{P}<0.05$.

The family Solanaceae is considered as one of the most cosmopolitan families of Angiosperms because it exhibits higher morphological diversity (Jennifer and James, 1997; Bean, 2004, Knapp et al., 2004). In the present study, it was observed that, Solanaceous species are morphologically diverse and the PC analysis followed by cluster procedure was able to discriminate all the species into unique groups. The species Sudhu Aththana is 12\% morphologically similar to the rest simply because it does not belong to the genus Solanum. However the other Solanum genotypes were also showing a significantly higher diversity and within the genus Solanum, Katuwelbatu could be considered as the local outgroup. Welthibbatu is very similar to Small Kalukenweriya than to other Thibbatu species. It has been reported that many morphological traits such as fruit size, shape and taste which are associated with the domestication process of eggplants are controlled by one or few genes (Frary et al., 2000; Doganlar et al., 2002; Van der Knapp and Tanksley, 2003; Cong et al., 2008; Xiao et al., 2008; Wang et al., 2008). Hence assortment and preservation of germplasm exclusively based on morphological features can be uncertain as morphologically dissimilar accessions may differ by only one or two alleles (Tumbilen et al., 2011). The morphological traits are also affected by micro climatic conditions although samples were collected from the same province. Therefore molecular methods coupled with morphological analysis are preferred for proper germplasm characterization and conservation (Sifau et al., 2014). Morphological features are inadequate to establish a genetic relationship especially for the species like Solanum, which are capable of crossing with more distant species (Daunay et al., 1999). It is also possible to trace out and scientifically document the changes 
in the pathways of domestication process through genetic diversity analysis (Doebley et al., 1997) which could be a potential next step of the present study.

The precise identification of species is very important for efficient utilization of medicinally important Solanaceous species in Ayurvedic and herbal medicine industry. Analysis of genetic polymorphism is an efficient tool for the utilization and conservation of plant genetic resources because morphological keys are effective only for a particular stage of life (Sifau et al., 2014). The medicinal plants such as ginger, ginseng, bamboo and moringa have been characterized using DNA barcoding loci (Cortese et al., 2010). The barcoding locus matk is preferred by many taxonomists and applied biologists because of its high polymorphism. In the present study, mat $K$ was chosen because it provided greater DNA polymorphism among the Solanaceous spp (Yu et al., 2011).

The matK polymorphism among 14 Solanaceous genotypes revealed that Wambatu genotypes and Elabatu genotypes are all belonging to same species $S$. melongena as reported in Dassanayake and Fosberg, (1988). However according to the morphological diversity assessments these genotypes are distinctly different from each other. It is not logical to think that these genotypes are different species but, some major genes or quantitative trait loci (QTL) would cause the variations in fruit and plant morphology. To efficiently characterize these genotypes which share same matk sequence, the underlying genes / QTLs for the fruit and leaf variation must be characterized. However sequencing of other DNA barcoding loci would also provide an absolute judgment to include all Wambatu and Ealabtu genotypes within the same species. It would also be interesting to see whether these Elabatu and Wambatu genotypes are crossing with each other creating higher morphological diversity due to potentially higher heterotic effects. The species Welthibbatu and Thiththathibbatu share the same matK locus implying that they are putatively belonged to same species therefore DNA barcoding of other loci is compulsory to establish their species limits.

The word Solanaceae is derived from Latin word 'Solari' which means to 'soothe' referring to its pharmacological properties (Yousaf et al., 2008), which are due to alkaloids (Friedman and McDonald, 1997) in which solanin, solasodine, scopolamine, atropine and hyoscyamine are considered as the major ones (Stanker et al., 1994). In Sri Lanka, the roots of Solanaceous species are predominantly used in Ayurvedic medical preparations. Out of the 14 species studied Katuwelbatu, all Ealabatu, Sudhu Aththana, Small Kalukenweriya and Walthibbatu are used for the medicinal purposes. However the species Gonabatu, Thiththathibbatu and Welthibbatu which are considered as medicinally not important species have significant antibacterial activity against model pathogens. All these species have significantly higher antibacterial activity compared to the control and S. aureus was affected more by the root extracts than E. coli. This is because of the presence of bilayer cell membrane in Gram negative E. coli compared to Gram positive $S$. aureus which has a single cell membrane. It is important to document the antibacterial activity against the model pathogens to conduct future assays on specific virulent pathogens. The disc diffusion method can be used to detect the antibacterial activity of series of concentrations to determine the minimum inhibitory concentration for the root extracts of Solanaceous spp.

The morphological variation assessment, matK DNA barcodes and antibacterial activity against the model pathogens in combination provide a strong platform to use these Solanaceous species in Ayurvedic and herbal medicinal industries in Sri Lanka. 


\section{CONCLUSIONS}

The morphological assessment of the commonly grown nine Solanaceous species revealed high diversity. The matK based DNA barcoding revealed that all the Wambatu and Elabatu genotypes share the same haplotype, Thiththathibbatu and Walthibbatualso share a common haplotype and other six species have unique haplotypes. The significantly highest antibacterial activity was observed in Gonabatu and Thiththathibbatu against E.coli and in Walthibbatu against $S$. aureus.

Acknowledgements: Royal Botanical Gardens, Peradeniya, Department of National Botanic Gardens, Sri Lanka for facilitating sample identification process.

\section{REFERENCES}

Abbas, K., Niaz, U., Hussain, T., Saeed, M.A., Javaid, Z., Idrees, A. and Rasool, S. (2014).Antimicrobial activity of fruits of Solanum nigrum and Solanum xanthocarpum. Acta Pol. Pharm. 71, 415 - 421.

Adam, G., Huong, H.T. and Khoi, N.H. (1979). The constituents of the Vietnamese drug plant Solanum verbascifolium L. Planta Med. 36, 238 - 239.

Adam, G., Huong, H.T. and Khoi, N.H. (1980).Solaverbascine - a new 22, 26epiminocholestane alkaloid from S. verbascifolium.Phytochemistry. 19, 1002 - 1003.

Adesina, S.K. (1985). Constituents of Solanum dasyphyllum fruits.Lloydia. 48, 147.

Ahmed, A., Tayela, E. and Wael, F. (2013). Production of anticandidal cotton textiles treated with oak gall extract. Rev. Argent. Microbiol. 45, 271 - 276.

Amer, W.M., Abouwarda, A.M., Garfia, E.L., Dawoud, G.T.M. and Abdelmohsen, G. (2013).International Journal of Biology, Pharmacy and Allied Sciences (IJBPAS). 2(6), 1282 $-1306$.

Bahgat, A., Abdel, A., Raafat, M., Mahdy, A., ELkhatib, A., Ismail, A. and Khayyal, M. (2008).Solanum indicum spp. distichum extract is effective against L-NAME induced hypertension inrats. Fundam.Clin.Pharmacol.22(6), 693 - 699.

Bansal, S., Singh, K. and Kumar, S. (2009). Larvicidal activity of the extracts from different parts of the plant Solanum xanthocarpum against important mosquito vectors in the arid region. J. Environ. Biol. 2, 221 - 226.

Bean, A.R. (2004). The taxonomy and ecology of Solanumsubg.Leptostemonum (Dunal) Bitter (Solanaceae) in Queensland and far North-Eastern New South Wales, Australia. Austrobaileya. 6(4), 639 - 816.

Bello, S.O., Muhammad, B.Y., Gammaniel, K.S., Abdu-Aguye, I., Ahmed, H., Njoku, C.H., Pindiga, U. H. and Salka, A.M. (2005).Preliminary Evaluation of the Toxicity and Some Pharmacological Properties of the Aqueous Crude Extract of Solanum melongena. Res. J. Agric. and Biol. Sci. 1(1), 1 - 9. 
Bose, B. and Ghosh.C. (1980). Studies on the variation of chemical constituents of S. nigrum ripe and unripe berries. J. Inst. Chem. 52(2), 83 - 84.

Britto, A.J., Gracelin, D.H.S. and Rathna Kumar, P.B.J. (2011). Antimicrobial activity of a few medicinal plants against gram negative bacteria. Int. J. Appl. Biol. Pharm. 2(3), 457 461.

Chen, R., Feng, L., Li, H.D., Zhang, H. and Yang, F. (2009). Two novel oilgosaccharides from Solanum nigrum. Carbohydr. Res. 344, 1775-1777.

Chinedu, S.N., Olasumbo, A.C., Eboji, O.K., Emiloju, O.C., Arinola, O.K. and Dania, D.I. (2011). Proximate and phytochemical analyses of Solanum aethiopicum L. and Solanum macrocarpon L. fruits. Res.J.chem.sci. 1(3), 2231 - 606.

Cong, B., Barrero, L.S. and Tanksley, S.D. (2008). Regulatory change in YABBY-like transcription factor led to evolution of extreme fruit size in tomato domestication. Nat. Genet. 40, 800 - 804 .

Cortese, L.M., Honig, J., Miller, C. and Bonos, S.A. (2010).Genetic diversity of twelve switch grass population using molecular and morphological markers. Bioenergy Res. 5(3), $262-271$.

Cuthbertson, A.G.S. and Murchie, A.K. (2005). Economic spray thresholds in need of revision in Northern Irish Bramley orchards. Biological News. 32, 19.

Dassanayake, M.D. and Fosberg, F.R. (1988). A revised handbook of the flora of Ceylon, Vol 6, CRC Press, Sri Lanka.

Daunay, M.C., Dalmon, A. and Lester, R.N. (1999). Management of a collection of Solanum species for eggplant (Solanum melongena L.) breeding purposes. pp. 369-383. In: Nee, M., Lester, R.N. and Jessop. J.P. (Ed.) Solanaceae IV, Advances in Biology and Utilization, Royal Botanic Gardens, Kew.

De Sousa, R.R., Queiroz, K.C., Souza, A.C., Gurgueira, S.A., Augusto, A.C., Miranda, M.A., Peppelenbosch, M.P., Ferreira, C.V. and Aoyama, H. (2007). Phosphoprotein levels, MAPK activities and NF kappaB expression are affected by fisetin, J. Enzyme Inhib. Med. Chem. 22(4), 439 - 444.

Devi, S., Gupta, A.K. and Singh, M. (2012). Ethano-Medicinal use of plants belonging to families Fabaceae and Solanaceae, Hamirpur District (H.P).ISSN 2250 - 3153.

Dhellat, J.R., Matouba, E., Maloumbi, M.G., Nzikou, J.M., Dzoudo, M.G., Linder, M., Parmenite, M. and Desobry, S. (2006). Afr. J. Biotechnol.5, 987.

Dobson, C.R. (2010). Medicinal Natural Product. A Biosynthetic Approach, Willey and Sons, pp. 925-978.

Doebley, J., Stec, A. and Hubbard, L. (1997). The evolution of apical dominance in maize. Nature. 386, 485 - 488. 
Doganlar, S., Frary, A., Daunay, M.C., Lester, R.N., Tanksley, S.D. (2002). Conversation of gene function in the Solanaceae as revealed by comparative mapping of domestication traits in eggplant. Genetics. 161, 1713 - 1726.

Doss, A., Mubarack, H. and Dhanabalan, R. (2009). Antibacterial activity of tannins from the leaves of Solanum trilobatum Linn. Indian J. Sci. Technol. 2(2). 41 - 43.

Edem, Christoper, A., Dosunmu, Miranda, I., Bassey, Francisca, I., Wilson, Charles, Umoren and Patience. (2009). A comparative assessment of the proximate composition, ascorbic acid and heavy metal content of two species of garden egg (Solanum gilo and Solanum aubergine). Pakistan J. Nutrition. 8(5), 582 - 584.

Edmonds, J.M. and Chewya, J.A. (1997). Black Nightshades: Solanum nigrum L. and related species.Promoting the conservation and use of underutilized and neglected crops.International Plant Genetic Resources Institute (IPGRI), Rome, Italy.pp.159.

Fazekas, A.J. (2008). Multiple multi-locus DNA barcodes from the plastid genome discriminate plant species equally well. PLoS ONE.3, e2802.

Fontem, D.A. and Schippers, R.R. (2004). Solanum scabrum Mill. pp. 493-498. In: Grubben G.J.H.and Denton O.A. (Ed.) In: Plant Resources of Tropical Africa. PROTA Foundation. Backhuys Publishers., Leiden, Netherlands.

Frary, A., Nesbitt, T.C., Frary, A., Grandillo, S., Van der Knaap, E., Cong, B., Liu, J., Meller, J., Elber, R., Alpert, K. and Tanksley, S. (2000). Fw2.2: a quantitative trait locus key to the evolution of tomato fruit size. Sci. $289,85-88$.

Friedman, M. and McDonald, G.M. (1997). Potato glycol alkaloids: Chemistry, analysis, safety and plant physiology. Crit. Rev. Plant Sci. 16 (1), 55 - 132.

Gao, X., Zhu, Y.P., Wu, B.C., Zhao, Y.M., Chen, J.Q. and Hang, Y.Y. (2008). Phylogeny of Dioscorea sect.Stenophora based on chloroplast $m a t K, r b c L$ and $t r n L-F$ sequences. J. Syst. Evol.46, 315 - 321.

Gbile, Z.O. and Adesina, S.K. (1988). Nigerian Solanum species of economic importance. Ann. Missouri Botanical Garden.75, 862 - 865.

Gupta, S., Mal, M. and Bhattacharya, P. (2005). Evaluation of hypoglycemic potential of Solanum xanthocarpum (Solanaceae) fruits in normal and streptozotocin induced diabetic rats. European Bull. Drug. Res. 13.

Huang, W.H., Hsu, C.W. and Fang, J.T. (2008). Central diabetes insipidus following digestion Solanumindicum L. concentrated solution. Clin.Toxicol. 46 (4), 293 - 296.

Igwe, S.A., Akunyili, D.N. and Ogbogu, C. (2003). Effects of Solanum melongena (garden egg) on some visual functions of visually active Igbos of Nigeria, J. Ethnopharmacol. 86(23), $135-138$.

Jain, R., Sharma, A., Gupta, S., Sarethy, I.P. and Gabrani, R. (2011). Solanum nigrum: current perspectives on therapeutic properties. Altern. Med. Rev. 16 (1), 78 - 85. 
Jain, S.C and Sahoo, S.L. (1981a). Solanum verbascifolium suspension cultures. Pharmazie. $36,714-715$.

Jain, S.C. and S.L. Sahoo. (1981b). Isolation and characterization of steroidal sapogenins and glycoalkaloids from Solanum verbascifolium L. Chem. Pharm Bull. 29, 1765 - 1767.

Jain, S.K. (1968). Medicinal Plants. Thomson Press Ltd, India, pp. 133-134.

Jayanthy, A., Sulaiman, C.T. and Rema Shree, A.B. (2012). Pharmacognostical and phdytochemical comparison of roots of Solanum species used in ayurvedic formulations. Int. Pharmacognosy and Phytoche. Res. 4 (1), 28 - 37.

Jennifer, M.E. and James, A.C. (1997). Black nightshades Solanum nigrum L. and related species. International Plant Genetic Resources Institute. Rome, Italy.

Jian, L., Qingwang, L., Tao, F. and Kun, L. (2008). Aqueous extract of Solanum nigrum inhibit the growth of cervical carcinoma (U14) via modulating immune response of tumor bearing mice and inducing apoptosis of tumor cells. Fitoterapia. 79(7-8), 548 - 556.

Kaushik, D., Jogpal, V., Kaushik, P., Lal, S., Saneja, A., Sharma, C. and Aneja, K.R. (2009). Evaluation of activities of Solanum nigrum fruit extract. Arch. Appl. Sci. Res. 1(1), 43 - 50.

Knapp, S., Bohs, L., Nee, M. and Spooner, D.M. (2004). Solanaceae- a model for linking genomics with biodiversity. Comp. Funct. Genom. 5, 285 - 291.

Kumar, P.S., Sucheta, S., Deepa, V.S., Selvamani, P. and Latha, S. (2008). Antioxidant activity in some selected Indian medicinal plants. Afr. J. Biotechnol. 7, 1826-1828.

Lahaye, R. (2008). DNA barcoding the floras of biodiversity hotspots.PNAS. 105, 2923 2928.

Li, X.X. and Zhou, Z.K. (2007). The higher-level phylogeny of monocots based on matK, $r b c L$ and $18 \mathrm{~S}$ rDNA sequences. Acta Phytotaxon. Sin. 45, 113 - 133.

Ma, P., Cao, T.T., Gu, G.F., Zhao, X., Du, Y.G. and Zhang, Y. (2006). Inducement effect of synthetic indiosides from Solanum indicumL. on apoptosis of human heptocarcinoma cell line Bel-7402 and its mechanism. Chin. J. Cancer. 25(4), 438 - 442.

Marasinghe M.M.P.C., Mawalagedara S.M.U.P., Ishan M., Dunuwille S.W.M.B., Janaththani P., Dayananda A.G.M.L.K., Weebadde C.K., Yakandawala D.M.D. and Sooriyapathirana S.D.S.S. (2016). DNA based Authenication of Solanum melongena var. insanum (V. Elabatu) roots in herbal medicine market to circumvent the use of noxious adulterant, Solanum melongena (V. Eggplant) roots. J. Sci., Eastern University, Sri Lanka. 7, $35-52$.

Mueller, L.A., Solow, T.H., Taylor, N., Skwarecki, B., Buels, R., Binns, J., Lin, C., Wright, M.N., Ahrens, R., Wang, Y., Herbst, E.V., Keyder, E.R., Menda, N., Zamir, D. and Tanksley, S.D. (2005). The SOL genomic network.A comparative resource for Solanaceae biology and beyond. Plant Physiol.138, 1310 - 1317.

Nadkarni, K.M. (1927). Indian Materia Medica, Bombay. 
Noda, Y., Kneyuki, T., Igarashi, K. and Packer, M.L. (2000). Antioxidant activity of nasunin, an anthocyanin in eggplant peels, Toxicol. 148, $119-123$.

Odetola, A.A., Iranloye, Y.O. and Akinloye, O. (2004).Hypolipidaemic potentials of Solanum melongena and Solanum giloon hypercholesterolemic rabbits. Pakistan J.Nutr. 3(3), 180-187.

Ogundajo, A.L., Oladosu, I.A., Ogundawe, Flamini, G. and Owolabi, M.S. (2013). Study on the volatile constituents of Solanum nigrum var. virginicum L. from Nigeria. Asian J. Plant and Res. 3(1), 94 - 98.

Ojewole, J.A.O. and Adesina, S.K. (1983). Cardiovascular and neuromuscular actions of scopoletin isolated from the fruit of T. tetraptera. Taub. Planta Med, 10,49-99.

Parameswari, K., Aluru, S. and Kishori, B. (2012). In vitro antibacterial activity in the extracts of Solanum nigrum, Indian Streams Res. J. 2, 1 - 4.

Pari, L. and Umamaheswari, J. (2000).Antihyperglycaemic activity of Musa sapientum flowers: Effect on lipid peroxidation in alloxan diabetic rats. Phytother. Res. 14, 136 - 138.

Perrier, X. and Jacquemoud-Collet, J.P. (2006). DARwin software. Available at http://darwin.cirad.fr/

Perrier, X., Flori, A. and Bonnot, F. (2003). Data analysis methods. pp. 43-76. In: Hamon, P., Seguin, M., Perrier, X. and Glaszmann, J.C. (Ed.) Genetic diversity of cultivated tropical plants. Enfield, Science Publishers, Montpellier.

Raj, S.K. and Suchitra. (2009). Evaluation of antimicrobial potential of different extracts of Solanum xanthocarpum Schard and Wendl. Afr. J. Microbiol. Res. 3, 97 - 100.

Rao, C.K. (2011). Use of brinjal (Solanum melongena L.) in alternative systems of medicine in India.Foundation for Biotechnology Awareness and Education. Bangalore, India.

Ross, J.A. and Kassum, C.M. (2012). Dietary saponins availability, metabolic effects and safety. J. Ann. Rev. Nutrition. 24(3), 19 - 30.

Saijo, R., Murakami, K., Nohara, T., Tomimatsu, T., Sato, A. and Matsuoka, K. (1982). Studies on the constituents of Solanum plants. II. On the constituents of the immature berries of S. nigrum L. Yakugaku Zasshi. 102, 300 - 305.

Segal, R., Milo-Goldzweig I. and Zaitschek. D.V.(1977). Diosgenin and yamogenin from $S$. incanum. Lloydia. 40, 604.

Sekara, A., Cebula, S. and Kunicki, E. (2007). Cultivated eggplants-origin, breeding objectives and genetic resources, a review. Ann. Hort. 19(1), 97 - 114.

Sheeba, E. (2010). Antibacterial activity of Solanum surattense Burm.F. Kathmandu University Journal of Science, Engineering and Technology. 6, 1 - 4. 
Sifau, M.O., Akinpelu, A., Ogunkanmi, L.A., Adekayo, K.O., Oboh, B.O. and Ogundipe, O.T. (2014). Genetic diversity in Nigerian brinjal eggplant (Solanum melongena L.) as revealed by random amplified polymorphic DNA (RAPD) markers. Afr. J. Biotech. 21, 2119 $-2126$.

Singh, O., Subharani, K., Singh, N., Devi, N. and Nevidita, L. (2007).Isolation of steroidal Glycosides from Solanum xanthocarpum and studies on their antifungal activities. Nat. Prod. Res. 21, 585 - 590 .

Singh, V.K., Ali, Z.A., Zaide, S.T.H., Siddiqui, M.K. (1996). Ethnomedicinal uses of plants of Gonda district forests of Uttar Pradesh, India. Fitoterpia. 67(2), 129 - 139.

Sohrabipour, S., Kharazmi, F., Soltani, N. and Kamlinejad, M. (2014). Biphasic effect of Solanum nigrum fruit extract on vascular mesenteric beds in non-diabetic and streptozotocininduced diabetic rats. Pharmacogn. Res.6 (2), 148 - 152.

Soni, P., Siddiqui, A.A., Dwivedi, J. and Soni, V. (2012).Pharmacological properties of Datura stramonium L. as a potential medicinal tree.Asian Pac. J. Trop. Biomed. 12, 1002 1008.

Stanker, L.H., Kamps-Holtzapple, C. and Friedman, M. (1994).Development and characterization of monoclonal antibodies that differentiate between potato and tomato glycoalkaloid and aglycons. Agric. Food Chem.42, 2360 - 2366.

Sudheesh, S., Presannakumar, G., Vijayakumar, S. and Vijayalashmi, N.R. (1997).Hypolipidemic effect of flavonoids from Solanum melongena.Plant Foods Hum. Nutr.51, $321-330$.

Taherpour, A., Khodaei, M.M., Ameen, B.A.H., Ghaitouli, M., Mahdizadeh, N., Amjadian, H.R. and Larijani, K. (2013).Chemical composition analysis of the essential oil of Solanumnnigrum L. by HS/SPME method and calculation of the biochemical coefficients of the components.Arabian Journal of Chemistry.[Accessed on 24.12.2015].Available at http://dx.doi.org/10.1016/j.arabje.2013.08.015.

Tamboli, E.T., Chester, K. and Ahmad, S. (2015). Quality control aspects of herbs and botanicals in developing countries: Coleus forskohlii Briq: a case study. J. Pharm. Bioallied. Sci. 7(4), 254 - 259.

Taye, B., Giday, M., Animut, A., Seid, J., (2011).Antibacterial activities of selected medicinal plants in traditional treatment of human wounds in Ethiopia. Asian Pac. J. Trop. Biomed. 5, 370 - 375.

Trease, G.E. and Evans, W.C. (2011). Pharmacognosy. Braillian Tridal, Macmillian Publishers, Canada, pp. 89-95.

Tumbilen, Y., Frary, A., Mutlu, S. and Doganlar, S. (2011).Genetic diversity in Turkish eggplant (Solanum melongena) varieties as determined by morphological and molecular analyses. Int. Res. J. Biotech. 2(1), 016 - 025. 
Van der Knapp, E. and Tanksley, S.D. (2003). The making of a bell pepper - shaped tomato fruit: identification of loci controlling fruit morphology in Yellow Stuff tomato. Theor. Appl. Genet.107, 139 - 147.

Vejdemo-Johansson, M., Vejdemo, S. and Ek, C. (2014). Comparing distributions of color words: Pitfalls and metric choices. PLoSONE. 9, e89184.

Ven Murthy, M.R., Ranjekar, P.K., Ramassamy, C. and Deshpande, M. (2010). Scientific basis for the use of Indian ayurvedic medicinal plants in the treatment of neurodegenerative disorders: ashwagandha. Cent.Nerv. Syst. Agents Med. Chem. 10(3), 238 - 246.

Vohora, S.B., Kumar, I. and Khan, M.S.Y. (1984).Effect of alkaloids of Solanum melongena on the central nervous system, J. Ethnopharmacol. 11, 331 - 336.

Wang, J., Gao, T. and Knapp, S. (2008). Ancient Chinese literature reveals pathways of eggplant domestication. Ann. Bot. 102, 891 - 897.

WHO.(2013). WHO Traditional medicine strategy 2014-2023, World Health Organization.

Xiao, H., Jiang, N., Schaffner, E., Stockinger, E.J. and Van der Knaap, E. (2008).A retrotransposon-mediated gene duplication underlies morphological variation of tomato fruit. Sci. $319,1527-1530$.

Yousaf, Z., Masood, S., Shinwari, Z.K., Khan, M.A. and Rabani, A. (2008). Evaluation of taxonomic status of medicinal species of the genus Hyoscyamous, Withania, Atropa and Datura based on poly acrylamide gel electrophoresis. Pakistan J. Bot. 40(6), 2289 - 2297.

Yu, J., Xue, J.H. and Zhou, S.L. (2011). New universal matK primers for DNA barcoding of angiosperms. J. Syst. Evol. 49(3), 1762 - 1781. 